Artigos Assinados 


\section{Teatro e Estado do Barroco}

\section{OTTO MARIA CARPEAUX}

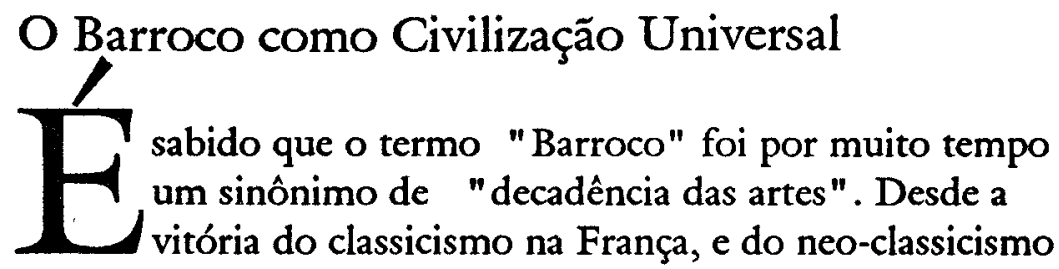

na Alemanha, as comparaçōes entre a arte clássica da Renascença e a arte "moderna" do Barroco pululam, e estas comparaçóes sempre produzem maus resultados para o Barroco. As primeiras ediçóes do Cicerone, de um tão grande conhecedor como Jacob Burckard testemunham-no; mesmo os Kunstgeschichtliche Grundbegriffe de seu sucessor Heinrich Woefflin, em 1915, ressentem-se desse fato. É perfeitamente possível que uma fina sensibilidade dos historiadores, a maioria deles protestantes, para a alma católica do Barroco tenham alguma responsabilidade nisso.

Desde há algumas décadas, esse aspecto mudou radicalmente. $\mathrm{O}$ Barroco, sua arte, sua literatura, sua ciência, sua política, foram objeto de muitos estudos, de um interesse apaixonado até ao modismo esnobe. Assistimos a uma verdadeira revalorização do Barroco. Bartolomé Manuel Cossio, Eugenio d'Ors, e os historiadores literários pós-menendizianos na Espanha, T.S. Eliot e Sacheverell Sitwell na Inglaterra, Paul Frankl e Ernst Cysarz na Alemanha, a lista deveria continuar; mas pouco adiantaria citar aqui nomes e obras. $\mathrm{O}$ movimento "barroquista" mereceria um estudo à parte, pois não se trata aqui de um negócio dos especialistas ou dos esnobes. Nosso tempo tem certas afinidades com o tempo barroco: nossas angústias religiosas, nossos abalos políticos e sociais, nossas preferências artísticas fizeram-nos compreender o Barroco, por mais de um motivo. Compreendemos nele, agora, um "sistema de civilização", o último " sistema fechado de civilização", o último "estilo" que a Europa produziu. O Barroco deixou de ser um fato histórico, para ser uma atualidade viva.

A alma da vida barroca é de substância latina, mediterrânea. É entre os povos latinos que o Barroco floresceu principalmente, e A.E. 
Brinckmann (1) sustenta uma afinidade especial entre as civilizaçóes mediterrâneas e as expressóes barrocas. Mas certas expressóes artísticas do Barroco - a decoração das igrejas e dos conventos, sobretudo elevam-se a seu ponto mais alto na Bélgica, na Alemanha Meridional, na Áustria, entre os povos germânicos, muito longe do Mediterrâneo, ligados às civilizaçōes latinas apenas pela fé comum, a fé católica reafirmada pelo Concílio de Trento.

Com efeito, as fronteiras geográficas do estilo barroco parecem coincidir com as fronteiras das religióes no século XVII, fronteiras criadas por esse grande movimento eclesiástico pós-tridentino que se chama, um pouco erroneamente, "Contra-Reforma". O Barroco floresce em Roma e em toda a Itália, sobretudo nas regióes muito fiéis, em Nápoles e no Piemonte; o Barroco floresce na Espanha e em suas possessões americanas, na Áustria, na Baviera e Francônia, na Bélgica; na Alemanha, a fronteira das confissóes coincide exatamente com a fronteira dos estilos. A França, ao contrário, profundamente perturbada pelas discussões jansenistas, abandona logo o Barroco; Bernini não podia ter lugar aí, e o classicismo venceu, nas artes como nas letras, o estilo barroco, ao qual os países protestantes, em geral, escapam. Werner Weisbach (2) baseou, sobre esses fatos, uma teoria, cujo conteúdo está resumido no título de seu livro: O Barroco como arte da Contra-Reforma. Isso quer dizer que o Barroco é a expressão deste estado de alma dos povos católicos que o Concílio de Trento preparou, e que seus executores criaram.

No fundo, esta teoria retoma, com mais vigor, uma expressáo que se encontra em muitas histórias das belas-artes: "estilo jesuítico". As vitórias da Contra-Reforma - conservemos o termo inexato, mas cômodo - deveram-se, como se sabe, principalmente aos jesuítas. Onde chegaram, reconstruíram as igrejas devastadas ou as edificaram novas, e preferiram um gosto artístico que se chamou outrora "estilo jesuítico" e que se prefere agora chamar "Barroco". Werner Weisbach aplicou este termo a todas as expressóes da alma católica, de 1580 a 1700 aproximadamente e muitos estudos especializados parecem dar-lhe razão.

Recorde-se, por exemplo, a expansão internacional do teatro dos Jesuítas que influenciou tão profundamente os teatros nacionais: Jacobus Gretser e Jacobus Bidermann na Baviera, Nicolaus Avancinus na Áustria, Nicolas Coussin na França, Johannes Surins na Bélgica,

(1) A.E.Brinkmann - Die Baukunst der romanischen Volkesäin 16. und 17 Jabrbundert, 1932.

(2) Werner Weisbach - Das Barock als Kunst der Gegenreformation, 1921. 
Alessandro Donati em Roma, Luiz da Costa em Portugal, até Franciscus Bohomolei na Boêmia e Gregorius Knapski na Polônia (3).

Contra todas as suas observações, é preciso reter que o estilo barroco, de inspiração católica sem dúvida, ultrapassou as fronteiras religiosas. Há um Barroco protestante. Isto prova que o catolicismo era, no século XVII, mais forte do que se imaginava; o Barroco é um fenômeno católico e ao mesmo tempo universal, o último deste gênero na Europa, e o estudo de suas expressōes protestantes permitirá dar-lhe uma definição mais exata.

Há um Barroco protestante. Os historiadores da literatura holandesa sempre o souberam, tinham necessidade dele para explicar Toost Van Vondel, seu maior poeta (4). Paralelamente, Alois Riegl (5) descobriu a essência barroca dos famosos "retratos de grupo" holandeses, e F.Schmidt-Degenes seguiu-o nos seus estudos rembrandtianos. Na Inglaterra, devemos a T.S. Eliot (6) a descoberta de toda uma civilização barroca, esquecida: isso tornou o ouvido mais afinado para as expressóes barrocas no teatro jacobeu, e mesmo elisabetano: com efeito, Ben Jonson, o catolicizante Philipp Massinger, John Webster,

(3) Ele encontra esses nomes pouco conhecidos em Hans Stender - Das Jesuitendrama beiden Slawen, 1932.

(4) Gustav Kalff - Litteratuver en tooneel te Amsterdam in de zeventiende eeutw; of. agora Jan Huizinga - Nederlandsche beschaving des 17e ceuw, 1933.

(5) Alois Riegl -Das holländische Gruppenporträt (in: Jabrbuch de Kunstsammiungen des Kaiserbauses, Wien, 1902, vol. XXIII).

(6) T.S.Eliot - Homage to Jolm Dryden, 1924; For Lancelot Andrewes, 1928.

\section{Contra o Esquecimento}

Em dezembro de 1967, no Teatro Municipal de Săo Paulo, a entăo Faculdade de Filosofia, Ciências e Letras da USP fazia a última cerimônia pública de entrega de diplomas a seus alunos. O paraninfo: Otto Maria Carpeaux. Um estudante leu o discurso do homenageado, um discurso que, com clareza e paixão, nos encorajava na luta pela democracia e pelo socialismo no Brasil. De pé, ao lado, Carpeaux acompanhava a leitura com gestos enérgicos. A gagueira, que o mantivera fora das salas de aula, incapacitava-o também para a tribuna. $O$ orador e o professor que perdemos manifestava-se, porém, exuberantemente, na escrita, até que foi também aí silenciado pela ditadura militar.

Pouco antes desse silêncio imposto, o silêncio voluntário, sua despedida como estudioso da literatura. $\mathrm{Na}$ breve "Nota prévia" a uma seleção de seus ensaios, "Vinte e cinco anos de literatura" (1968), explica só ter escolhido de seus trabalhos os que pudessem ainda "inspirar interesse ao círculo de amigos da literatura". E acrescenta: "Mas já não me incluo nesse círculo. Considero encerrado o ciclo. Minha cabeça e meu coração estáo em outra parte. O que me resta, de capacidade de trabalho, pertence ao Brasil e à luta pela libertaçăo do povo brasileiro" .

Dez anos depois, dez anos de silêncio quase completo, em fevereiro de 1978, Carpeaux nos deixaria para sempre. Impossível avaliar nossa perda, 
Cyril Tourneur, John Ford são tão barrocos quanto Tirso de Molina ou Calderón, do mesmo modo que se compreende agora o "barroco subterrâneo" no teatro clássico dos franceses, em Corneille sobretudo (7). Karl Deutschbein (8) distingue mesmo na obra de Shakespeare um período do barroco, de que Macbeth é a criação suprema. A este propósito recordar-se-á que Macbeth era uma homenagem teatral ao rei Jaime I da Inglaterra, cuja corte estava inbuída de uma ciência política barroca de que nos ocuparemos. O "Barroco protestante" é sobretudo evidente na Alemanha luterana: teremos ocasião de citar os dramas barrocos de Andreas Gryphious e de Johan Casper von Lohenstein. D'Indy falou do "catolicismo íntimo de Johan-Sebastian Bach", e Ruthland Boughton vê a ortodoxia luterana de Bach como "fenômeno de fuga", fuga da tentação católica. Os novos estudos bachianos baseiam-se nos livros preferidos de sua biblioteca, esta literatura de prece e edificação luterana, em que Wilhelm Althaus podia encontrar influências da literatura mística dos jesuítas. Mas não é a única influência jesuítica na Alemanha luterana do século XVII: descoberta surpreendente dos estudos recentes que os teólogos luteranos das Universidades de Wittenberg e de Helmstaedt, os mais intransigentes dos intransigentes escondiam a ausência de uma filosofia luterana por meio de empréstimos tomados ao grande filósofo jesuíta Francisco Suárez (9). Uma influência mais íntima manifesta-se, enfim, quando se estudam os caminhos tortuosos da invasão da Alemanha luterana pela mística de Santa Teresa (10).

A digressão sobre o Barroco protestante forneceu-nos algumas datas apreciáveis: nosso estudo fará ainda compreender o significado dessa justaposição, aparentemente estranha, de Pierre Corneille, do rei Jaime I da Inglaterra e do Pe. Francisco Suárez S.J. . Todavia não há a definiçấo prometida do estilo barroco. O Barroco impóe-se-nos como o conjunto grandioso das obras arquiteturais de Borromini e de Wren, das esculturas de Montañés e de Bernini, dos quadros do Greco e de Rubens, do teatro jesuítico, calderoniano, jacobeu, das especulaçóes e das ciências pós-ecolásticas de Suárez e Campanella, de uma Igreja triunfante e de um Estado absoluto: conjunto que destrói irremediavelmente toda tentativa de definição. As épocas históricas,

(7) Cf. Th. Maulnier - Introduction à la poésic française, 1929.

(8) K. Deutschbein - Macbctis als Barockdrama, 1936.

(9) Ernst Lewalter - Spanisch-jesuitische und deutsch-luterische Metaphysik, Hamburg, Ibero-amerikanisches Institut, 1935.

(10) Max Wieser - Peter Poiret, der Vater der romanischen Mystik in Deutschland, 1931. 
os estilos artísticos, os estilos de pensar e de viver, não se definem.

Antes das construçóes sintéticas, são necessários os estudos especializados das expressōes principais. As expressóes principais do Barroco são seu teatro e seu Estado; as relaçōes entre um e outro nos diráo muita coisa.

\section{O Teatro do Barroco}

Todo grande teatro, todo teatro verdadeiramente grande é por essência político. Náo é por acaso que o teatro antigo e o teatro clássico de todas as ${ }^{*}$ naçóes modernas passam-se nas cortes dos reis. Para fazer bom teatro, $e_{\text {preciso }}$ saber o que é um rei. $O$ teatro barroco gostou da história de Demetrius, que os jesuítas foram os primeiros a encenar e Lope de Vega representou no Gran Duque de Moscovia; a história deste príncipe Demetrius, de que não se sabia exatamente se era o Tzar dos Russos ou um impostor. Em todas as grandes tragédias do Barroco trata-se de saber quem é o verdadeiro rei: Macbeth e o príncipe Segismundo, de La vida es sueño, suportam esta prova ordália. $O$ palco do teatro barroco significa verdadeiramente o mundo, o mundo político, mas também o mundo cósmico. A Hester de Pe. Jacobus Gretser S.J., representada em Munique com todos os refinamentos da montagem era a primeira peça de que "todo o mundo", o céu e o inferno inclusos, participava. Todo teatro barroco é o Gran teatro del mundo de Calderón; só que a cortina às vezes tira a vista das forças cósmicas que decidem, no palco, o destino humano. $O$ teatro barroco declara-se conscientemente uma "comédia da vida", como Lope de Vega não estabelece diferença

com essa greve de silêncio, que suportamos sem protesto.

Agora, doze anos prolongaram aquele silêncio, que já dura vinte e dois longos anos. É urgente recuperar a riqueza que herdamos, sem the conhecer sequer o montante: em 11 de julho de 1948, José César Borba, no Correio da Manha, lhe registrava o $500^{\circ}$ ensaio publicado no Brasil, em apenas sete anos, informando também que estavam concluídas as três mil páginas da "História da Literatura Ocidental"; em 1968, em estimativa conservadora, falava-se em 1.500 ensaios, só duzentos reunidos em livro.

Quase não lhe reeditam mais os livros; numerosos ensaios, a maioria, jazem em coleçōes de jornais, muitos fora de circulaçăo, esperando a famosa "crítica devoradora dos ratos". Por onde começar?

Talvez pelos órgăos públicos: a 26 de abril de 1979, O Estado de São Paulo noticiava: "Já na Biblioteca Municipal 'Mário de Andrade', seus 1.818 volumes, acrescidos de revistas e dos muitos recortes que Carpeaux reunia foram colocados numa sala especial.

Daqui a quatro meses, quando tudo estiver catalogado, encapado, os livros em ordem na nova casa, poderão ser lidos e consultados por qualquer leitor". Ao que se sabe, até agora, em 1990, o trabalho năo foi concluído.

Outra parte do arquivo pessoal, incluindo recortes, manuscritos, fotos e documentos particulares, pertence à 
entre uma atriz que representa uma rainha, $e$ uma verdadeira rainha:

"Luego piensas tu que reinas

Con mayor estimación?

La diferencia sabida es

Que les dura hora y media

Su comedia, y tu comedia

te dura toda la vida." (Lo fingido verdadero)

A comédia do Renascimento conhece a mesma concepçáo:

All the world's a stage

And all the men and women merely players,

diz Jacques, em As you like it de Shakespeare. Mas o destino dos autores-homens do teatro renascentista depende dos caprichos da deusa pagã Fortuna, enquanto a tragédia barroca reencontrou, em versão cristã, o Destino da tragédia antiga, representado pelas forças cósmicas, cujos representantes terrestres sáo a Igreja, o Estado e "o exército do diabo". A palavra "teatro", sinônimo de um divertimento alegre no Renascimento, retoma uma significação "política", se se entende por "política" o que os sociólogos barrocos chamam "política ortodoxa" ou "heterodoxa", "política de Deus ou do diabo" (11). O teatro barroco é, neste sentido também, um "Theatrum mundi"; é de "Theatrum mundi" que os cronistas-historiadores e os primeiros jornalistas do século XVII chamam suas relaçōes na cena política da Europa (12).

Deste modo, o teatro barroco assemelha-se menos ao teatro do Renascimento que ao teatro medieval, cuja cena englobava tanto o céu, quanto a terra e o inferno. Como o teatro medieval, os "Mistérios" e as "Rappresentazioni", o teatro barroco recorda as origens do teatro cristão na liturgia da Igreja. Chamou-se a liturgia um

"Gesamtkunstwerk", conjunto de todas as artes para servir de louvor a Deus. O teatro barroco é, da mesma forma, um "Gesamtkunswerk"; e não é uma comparação fácil, mas o resultado dos estudos mais recentes.

O teatro barroco é um "Gesamtkunstwerk", em que todas as artes servem aos fins da encenaçáo. A arquitetura desempenha nisso um papel fundamental; apreende-se a essência do teatro barroco nos

(11) Johanes Carammelis - Lobkowitz O.S.B., na biografia do Pe. Dominicus a Jesus Maria, 1655.

(12) Theatrum mundi, de Matthaeus Merian, etc. 
esboços das decoraçóes maravilhosas que os arquitetos nos deixaram, os Burnacini, os Galli-Bibbiena, os Grimaldi, os Servandoni, os esboços de palácios e de escadas reais, de jardins encantados, com suas perspectivas infinitas (13). Os arquitetos desenham também os costumes suntuosos, de uma variedade inesgotável, e ajudam a dispor os coros e os balés, servidos pelo novo estilo homofônico da música profana (14). Não há meio de expressão que não esteja aí representado: "O teatro é o centro da cultura barroca" (15). Pelo menos, tudo está representado aí. O Barroco é o estilo - e o tempo - da "representaçăo", por excelência. A mesma pompa contorna com suas suntuosidades a cena, a corte, $o$ altar. Tudo é " maravilhoso", "colossal", "prodigioso". Lembramo-nos de que a palavra "barrocco" significa, em italiano, "acumulação". Comparam-se as qualidades que os esteticistas barrocos ressaltam na música: a música deve ser "meravigliosa", "grandiosa", "massiccia", "miracolosa", deve "far lo stupore" e "colpire i sensi" (16).

Todas essas definiçóes aplicam-se "meravigliosamente" às artes $\mathrm{e}$ aos artifícios da encenação barroca, sobretudo no teatro dos jesuítas: há tempestades artificiais e fogos de artifício, máquinas que

(13) Resumo em Josef Gregor - Weltgeschichte des Theatere, 1933; cf. as publicaçóes da Biblioteca Nacional, de Viena, e do Museu do Teatro, de Colônia.

(14) Guido Adler n.a. - Dic Musik am Hofe der babsburgischen Kaiser des 17 und 18 Jabrbunderts, 1922-1924.

(15) Hans Alewyn - Der Geist des Barocktheaters, 1936.

(16) Luigi Corte - Mussica del Barocco, 1933.

Fundação Casa de Rui Barbosa, no Rio de Janeiro, e carece também de organizaçăo.

Sabe-se, além disso, que o Suplemento literário de $O$ Estado de São Paulo, entre 1958 e 1967, the publicou duzentos e dezesseis trabalhos, a maioria inédita em livro ...

O ensaio que ora apresentamos, "Teatro e Estado do Barroco", também aparentemente inédito, foi encontrado no acervo da Fundaçăo Casa de Rui Barbosa. É um manuscrito de dezenove páginas numeradas, redigido em francês, com tinta preta, em letras miúdas que se apertam em folhas amarelecidas de papel, e quase lhe ocupam os 22 $x 28 \mathrm{~cm}$. No canto esquerdo da primeira página, em diagonal, as palavras "Provavelmente 1942", escritas com a mesma grafia desse texto năo assinado, mas inequivocamente autógrafo. As rasuras fazem supor redação única, alteraçóes introduzidas no momento mesmo da escrita: não há entrelinhas.

Num futuro estudo sistemático que se fizer da obra de Otto Maria Carpeaux, é preciso levar em conta o contexto em que se insere o ensaio agora divulgado: forma conjunto com "A Cinza do Purgatório" (1942) e "Origens e Fins" (1943). O Autor, aliás, desejava vê-los reunidos, conforme se lê em nota ao último: "Peço considerar o livro como complemento ao volume anterior: 'A Cinza do Purgatório'. Săo partes dum esforço que, em contradição dialética e em unidade do pensamento, continua". 
arrebatam personagens pelos ares, apariçóes de deuses nas nuvens, jatos d'água e de chamas infernais; havia proezas, como a divisāo e a desaparição de nuvens, de que depois se esqueceu, e que a cena moderna não sabe mais reproduzir.

Todos esses artifícios estão condicionados, ou antes são conseqüências das duas grandes inovaçóes revolucionárias pelas quais o teatro barroco se distingue de todo teatro precedente: a perspectiva e a mudança de cena. As duas inovaçōes correspondem às transformaçōes de estilo, passando do Renascimento ao Barroco: a transiçáo da "forma fechada" à "forma aberta", do "estilo plano" ao "estilo profundo" (termos de Heinrich Woelfflin (17). A "profundidade" barroca corresponde à perspectiva; a "liberaçáo das fronteiras" barroca corresponde à liberdade de mudar de cena.

A perspectiva e a mudança de cena parecem inovaçóes exteriores; na verdade, são transformaçóes tão profundas que o sentido metafísico da arte teatral manifesta-se aí (18).

A perspectiva é uma qualidade do espaço; ela é própria a certos espaços enquanto outros espaços carecem dela. No teatro moderno, desde o barroco, o espaço da cena possui a perspectiva, enquanto o espaço dos espectadores, a sala, não. Por isso, os dois espaços estão radicalmente separados: o espaço na arquitetura do Renascimento $\epsilon$ "aditivo", o espaço na arquitetura do Barroco é "separativo" (19). Na Idade Média, o espaço dos espectadores e o espaço dos atores coincidem, todo mundo participa do espetáculo dos Mistérios; no Renascimento, os dois espaços se adicionam e se completam, avizinham-se; no Barroco, os dois espaços estão radicalmente separados. É uma transformaçáo radical. A cena se transforma, pela primeira vez, em um "mundo da ilusäo", independente do mundo real; um mundo ilusório, um mundo dos sonhos. E por isso que o assunto "sonho" é táo caro ao teatro barroco que encontra aí sua mais íntima substância, do

We are such stuff

As dreams are made on, and our little life Is rounded with a sleep,

pelo qual o Próspero de Tempest, de Shakespeare, exprime sua última

(17) Heinrich Woelfflin - Kounstgeschichtliche Grundbegriffe, 1915.

(18) Alewyn, 1.c.

(19) Termos de Paul Frankd - Die Entwickluangsphousen der neweren Baukeunst, 1914. 
sabedoria, até a última sabedoria do príncipe Segismundo; na Vida es sueño, de Calderón.

El 'soñarlo solo basta;

Pues así llegué a saber

Que toda la dicha humana, Enfin, pasa como un sueño.

O mesmo mecanismo interior torna cara ao teatro barroco a cena dentro da cena, o desdobramento ilusionista da ilusáo, no terceiro ato de Hamlet como em $L$ illusion comique de Pierre Corneille. A perspectiva, a ilusão, o sonho, três aspectos de uma mesma concepção, são a alma do teatro barroco.

\section{O corpo material desta alma é a} mudança de cena. É preciso aí distinguir. Em Shakespeare e em Corneille, a concepção está toda nas palavras; pois o teatro elisabetano não conheceu a mudança de cena e o teatro francês a encontrava proibida pelas famosas "unidades". Sáo cenas "simultâneas". O teatro propriamente barroco é uma "cena sucessiva", e, por isso, um teatro de movimento. Até mesmo um teatro de movimento excessivo. "É como se um vento passasse pelas personagens do Barroco, como o vento que transforma os grupos plásticos dos altares barrocos em estatuária agitada" (20). O vento transforma em marionetes agitadas, mas sem vontade, as personagens barrocas, esse vento produz um balé mecanizado, um "perpetuum mobile". Recordem-se as palavras de George Meredith sobre o teatro espanhol, citadas por Azorin (21): " La comedia española se distingue

(20) Wilhelm Hausenstein - Der Geist des Barock, 1921.
Particularmente próximos de

'Teatro e Estado do Barroco' estão 'Max Weber e a Catástrofe' ("A Cinza do Purgatório") e 'Tradiçóos Americanas ' ("Origens e Fins"). Mais tarde, 1953, aprofunda monograficamente suas reflexóes no estudo de 'La vida es Sueño' ("A Torre", em "Respostas e Perguntas").

Antes de se expressar, aliás admiravelmente, em português, Carpeaux escrevia em francês os ensaios que eram, depois, vertidos para o português, $\mathrm{e}$ publicados em revistas e jornais. O trabalho de traduçáo era obra anônima, espécie de serviço de utilidade pública, generosa e espontaneamente oferecido, entre homens cultos, naqueles anos 40 . As traduçóes eram, em geral, excelentes. Isto não obstante, sobretudo no primeiro livro, "A Cinza do Purgatório", nota-se uma ou outra imprecisão. Lê-se, por exemplo, no estudo sobre Max Weber, a ocorrência de "interesses do capital", no lugar de "juros do capital". Uma reediçáo deverá estar atenta a essas particularidades, nem sempre negligenciáveis.

A publicaçăo deste inédito $\mathrm{e}$ estas breves indicaçōes introdutórias em Estudos Avanfados pretendem motivar uma batalha contra o injusto esquecimento de Otto Maria Carpeaux, e engajar-se nela.

\footnotetext{
* Zenir Campos Reis é professor do Departamento de Letras Clássicas e Vernáculas da Faculdade de Filosofia, Letras e Ciências Humanas da USP. Tradutor do texto de Otto Maria Carpeaux, publicado nesta ediçẩo.
} 
generalmente por lo rápido de los movimientos... La comedia española puede ser representada por un cuerpo de baile; y el recuerdo que deja su lectura se define con algo asi como el agitado arrastar de muchos pies". A vida na cena barroca é frenética, e o espectador aplaude as palavras do príncipe Segismundo:

Qué es la vida? Un frenesí.

Qué es la vida? Una ilusión.

Esses dois termos resumem um teatro barroco: uma concepçáo metafísica expressa por um balé ilusionista. $O$ balé exprime táo perfeitamente esta concepçáo que os autores e os espectadores tornam-se cada vez mais indiferentes às palavras, aos textos, até que o teatro barroco termine na ópera. Pode-se perseguir essa evoluçáo nas peças do Pe. Nicolaus Avancinus S.J., que termina libretista das óperas imperiais de Viena. As roupas, as danças, o acompanhamento musical, a arquitetura, as máquinas de água e de fogo invadem os textos $e$ expulsam as palavras. Aos homens, apenas restam alguns "soli", os germes da "aria" musical. Os atores perdem a individualidade, aglomeram-se nos coros, transformam-se em figurantes e comparsas mudos, peóes de um grande jogo de xadrez. O Barroco inventa o "balé do xadrez", jogos de xadrez dançados, nova expressăo da "comédia da vida"; a comparaçáo entre a vida e um jogo de xadrez aparece com freqüência na literatura barroca. Essa comparação é também cara à Idade Média, é verdade; mas nos "livros de xadrez" da Idade Média, as peças de xadrez representam as classes da vida social, a política interna, por assim dizer (22), e no Barroco as finezas do jogo representam as finezas da política exterior, da diplomacia. $O$ observador pessimista - o homem barroco é sempre pessimista inclina-se a olhar os reis e os povos como vítimas da diplomacia e de seus refinamentos diabólicos. Essa observaçăo produziu os tipos da tragédia barroca.

O herói da tragédia barroca é a vítima inocente das duas outras personagens principais, que o flanqueiam e o fazem cair: o tirano e $o$ intrigante. $O$ espírito barroco é moralista e moralizante, o que tem relaçáo com a renovaçáo moral do mundo católico pelo Concílio de Trento. Recordem-se os dois exércitos, do bem e do mal, os exércitos inacianos. No teatro barroco, todas as personagens sáo partículas do bem ou do mal, do alto ou do baixo, que pululam em torno de nós. Mas são "partículas". Em geral, não há diabos propriamente ditos. Se o diabo aparece na cena barroca, é expressamente chamado assim, o "Demónio" no Magico prodigioso de Calderón ou no Esclapo del demonio de Mira de Amescua. As personagens da tragédia barroca não

(22) Wilhelm Schwer - Stand und Stindeordnung in Weltbild des Mittelalters, 1934. 
As expressões principais do Barroco são seu teatro e seu Estado; as 'lações entre um outro nos dirão muita coisa.

são elas próprias demônios, são vítimas do demônio. Isso é também verdadeiro para o tirano e para o intrigante; săo antes mártires, vítimas de seu pessimismo excessivo (23). O tirano da tragédia barroca tem quase os traços de um santo, desesperado de sua salvaçáo. É profundamente melancólico, pois conhece a maldade do mundo. Perde-se em sua melancolia, debate-se entre a incapacidade de decisão e tempestades afetivas. $O$ mesmo desespero produz a atividade apressada e infatigável do intrigante. $O$ Barroco receia essas atividades misteriosas e os moralistas pessimistas à La Rochefoucauld procuram aí os segredos do diabo. O século XVIII, otimista, esquecerá as bases metafísicas dessas duas personagens terríveis: o tirano revelar-se-á personagem nobre e doce ou converter-se-á, como os sultōes de Voltaire, como o Saladino em Natan, o sábio de Lessing; o intrigante transforma-se em personagem cômica, embaraçado com ocupaçōes múltiplas e inúteis, nas comédias de Destouches e de Marivaux.

O drama barroco é pessimista. Os homens resistem penosamente ao mundo, por uma moral estóica, se não são salvos pela graça.

Sêneca é o modelo do teatro barroco: fornece-lhe muitos assuntos, fornece-lhe a psicologia terrificante, e, de certa maneira, a concepçáo da "comédia da vida". (Sêneca, Ep. ad Lucilium, LXXVI, LXXVII). Náo importa se o trágico Sêneca e o estóico Sêneca são idênticos; em todo caso, o Barroco acreditava nessa identidade. Sêneca fornece também ao teatro barroco a moral estóica. Deve-se acrescentar que o teatro barroco é, em grande parte, de origem espanhola, e a filosofia de Sêneca estava sempre em casa na Espanha. $O$ tirano aparece freqüentemente como melancólico estóico, por exemplo o Melancólico de Tirso de Molina, e Juan Perez de Montalbán intitula a tragédia do rei Felipe II: El gran Seneca de España Felipe II.

É inevitável. Náo há salvação definitiva fora da graça. Mas quando o clarăo da graça incide, a peça acabou. A graça só pode ser a conclusáo dramática. Até lá, o homem barroco só tem a moral estóica para resistir às tentaçóes do mundo. A tentaçầo é um assunto essencial do teatro barroco: Vida es sueño, Magico prodigioso, Macbeth, Phèdre, o Lucifer de Joost van Vondel. A tentação desempenha no teatro barroco o mesmo papel do Destino no teatro antigo: ela purifica pelo medo e humilhação (24).

Por isso a tragédia barroca não tem herói trágico, no sentido dos Antigos. Walter Benjamin (25) afirma mesmo que um verdadeiro herói

(23) Walter Benjamin - Der Ursprung des deutschen Trawerspiels, 1927.

(24) Deutschbein, 1.c.

(25) Benjamin, 1.c.

Estudos Avançados, 4(10) 
trágico é impossível no Barroco: "O espírito da Contra-Reforma" faz os homens dependerem diretamente da intervençáo celeste, o que torna impossível o conflito direto entre os homens, o conflito trágico. Benjamin explica, desse modo, a raridade de fins verdadeiramente trágicos no Barroco, e o final feliz de Vida es sueño é eloqüente.

Mas vejo, ao contrário, na "tentação" do teatro barroco, uma imitação intencional do Destino antigo, naturalmente em transformaçáo e interpretação cristãs. O próprio Benjamin define as personagens barrocas como "prisioneiras de constelaçōes funestas", o que recorda, ao mesmo tempo, Édipo e as crenças astrológicas, que sobreviveram ao século de Ticho de Brahe e de Wallenstein. Mas o destino astrológico é também transformado de forma cristã: o homem é prisioneiro do pecado geral do mundo; toda a Natureza está destinada à morte, motivo preferido da poesia barroca; a própria história humana é o caminho de paixão da humanidade.

É o grande assunto do espírito barroco: saber se e como o homem pode se subtrair a essa decadência natural e pecadora. As grandes "discussōes sobre a graça" dos Bañezistas e dos Molinistas, dos Jansenistas e dos Jesuítas tratam disso; no Condenado por desconfiado, Tirso de Molina representou essa discussão em cena. Como nesta peça, o teatro barroco, teatro católico, opta pelo livre arbítrio. A escravidáo da vontade às constelaçóes astrais aparece, na Vida es sueño, como erro perigoso, herético. Mas os que se entregam, voluntariamente, ao mundo, estáo condenados, é verdade, a ser marionetes, fantoches de suas paixóes mundanas; e muitos o sáo. É por isso que a cena barroca está repleta desses figurantes, até transformar-se em balé mudo. Isto parece um modo de expressão calvinista. Mas o teatro barroco é católico; por princípio, ele permanece fiel à vontade livre, que năo pode ser desmentida pelos "escravos do demônio"; Lanson sublinha que Corneille, aluno dos jesuítas de Rouen, afirma eloqüientemente o livre arbítrio em Oedipe, e "Polieucte é antes molinista; a graça de que se fala é a dos jesuítas, teólogos da liberdade, e antigos mestres do poeta" (26). Quando, no teatro barroco, a vontade humana é quebrada, isto significa, cada vez, que Deus ou o demônio venceu, mas pela livre decisão humana. Não é a escravidão da vontade, mas simplesmente a dependência religiosa do homem. Ainda uma vez, é preciso citar Paul Frankl (27): a transição do Renascimento para o Barroco é a transiçáo do espaço aditivo para o espaço separativo, da força independente e ativa para a força dependente e passiva, da liberdade puramente humana para a dependência religiosa. Na cena

(26) Gustave Lanson - Histoire de la litttrature frangaise, 12 ed., p. 438.

(27) Frankl, 1.c. 
... o teatro barroco érico em elementos cômicos cujo naturalismo grosseiro sublinha a futilidade do terrestre, para contrasta-lo com o sobrenatural

barroca, a liberdade humana subsiste, na medida em que ela se submete a Deus; quando ela resiste a Deus, o homem rebaixa-se a marionete do demônio; e a submissáo a Deus consiste em negaçáo voluntária do mundo.

O Barroco é um mundo de grandes preocupaçōes e de angústias religiosas (28). A "Contra-Reforma" afirma vigorosamente a vaidade do mundo, tema preferido da poesia barroca. Um pessimismo trágico dirige-se contra o mundo, perturbado pelo pecado, e o decompóe sistematicamente: a vida é apenas um sonho, sua pompa não passa de ilusão; esta atitude contém certa ironia, e a ironia é o avesso espiritual da ascese. Esta ironia exprime-se freqüentemente por meio do cômico, e o teatro barroco é rico em elementos cômicos cujo naturalismo grosseiro sublinha a futilidade do terrestre, para contrastá-lo com o sobrenatural (29). Trata-se sempre da luta entre o mundo e o sobrenatural, trata-se sempre de uma decisão (30). $O$ que se representa é o drama da salvação ou da condenação: o Doctor Cenodozus do Pe. Jacobus Bidermann, condenação eterna de um hipócrita, aparentemente salvo, é o auge do teatro barroco. Nas artes da encenaçáo, todas essas máquinas servem somente para fazer todo o Cosmos participar desse drama metafísico do homem. É o Gran Teatro del Mundo.

O meio artístico para representar aí todo o Universo, "vişibilia et invisibilia" , é a alegoria.

La alegoría no es más

Que un espejo que traslada

Lo que es con lo que no es.

(Calderón - El verdadero Dios Pan.)

A alegoria barroca é a expressáo artística de uma concepção muito católica, da "analogia entis". Para melhor compreender esta relaçáo, Hankamer (31) lembrou a epistemologia suareziana, a "fabricatio universalitatis" das datas especiais dadas ("dates spéciales données", N. do T.)

É no sentido dessa gnoseologia escolástica que Calderón define suas alegorias:

hacer más

representable un concepto.

(Sueños bay que verdaderos son.)

(28) G.Toffanin - La fine dell 'umarresimo, 1920.

(29) Hausenstein, 1.c.

(30) W.Hankamer - Dewusche Berrockdichtwong, 1936.

(31) Hankamer, 1.c.

Estudos Avançados, 4(10) 
A alegoria é a "fabricação de uma universalidade" servindo-se das datas dadas ("datés données", N. do T.) do mundo; a alegoria é a transcrição do mundo em um nível mais elevado, simbólico. Neste simbolismo, o mundo aparece ao pessimista melancólico do barroco como uma grande alegoria da morte. O mundo é radicalmente perturbado, seus movimentos não passam de uma perturbação insensata.

Qué es la vida? Un frenesí.

A alegoria quer abrir-nos os olhos: procura o verdadeiro lugar das verdadeiras entidades no mundo, os pontos de apoio ocultos da salvação neste mundo da morte. Para encontrá-los, é preciso destruir a fachada do mundo, é preciso provar que toda esta pompa é apenas sonho e ilusão; nunca é demais repetir as palavras de Calderón:

Qué es la vida? Un frenesí.

Qué es la vida? Una ilusión,

Una sombra, una ficción, $\mathrm{Y}$ el mayo bien es pequeño;

Que toda la vida es sueño, Y los sueños, sueños son.

É preciso destruir o mundo, a fim de que o homem possa manter-se: de outro modo, ele cairia na tragédia de tornar-se uma marionete muda, sem alma. É por isso que a tragédia barroca prega a vontade, é por isso que Corneille, o voluntarista, presta homenagem ao suaresianismo de seus mestres jesuítas. Todo o teatro barroco é o teatro da vontade. A própria morte do herói é sua vitória, pois na morte a perturbaçáo do mundo é vencida. $O$ abalo radical é magnificamente expresso pelo grande dramaturgo alemão Johan Cazier von Lohenstein:

Ia, wenn der Höchste wird vom Kirchhof sammeln ein Dann werd' ich Totenkopf ein englisch Antlitz sein.

(Se Deus ceifasse o cemitério, $\mathrm{Eu}$, cabeça de morto, seria uma face angélica.)

A tragédia barroca não tem necessidade de fim trágico. A própria morte é aí uma apoteose. A apoteose é a verdadeira conclusão do teatro barroco.

\section{O Estado do Barroco}

O plano deste estudo parece impor o tráçado das analogias entre ó teatro e o Estado barrocos. Isso não seria difícil; creio mesmó todas 
essas analogias muito fáceis, e enganadoras. As analogias se evidenciaráo por si mesmas, se um retrato fiel do Estado barroco for bem sucedido. Mas as dificuldades de uma definiçáo aparecem. A realidade do Estado barroco é assunto dos historiadores que sucumbem, até aqui; à abundância da documentaçăo, $\mathrm{e}$ a teoria política do Barroco, cujo estudo de fato valeria a pena, está toda imbuída de imagens utópicas, que têm uma relaçáo apenas muito indireta com a realidade. Resta somente o caminho de construir, segundo o método de Max Weber (32), um "Idealtypus" (tipo ideal) do Estado barroco. A comparaçáo entre esse "tipo ideal" e a estrutura espiritual do teatro barroco fornecerá a relaçáo procurada com a realidade política.

Terminamos o quadro do teatro barroco pela "Apoteose"; podemos começar, pela apoteose, o quadro do Estado barroco. Com efeito, o Estado barroco é a apoteose do monarca. O rei representa, "hic et nunc", a glória do outro mundo. Como homem, ele participa do mundo e da morte; como soberano, pertence já a um outro nível da hierarquia universal.

A representaçăo material dessé " hic et nunc" é a pompa da corte que iguala todas as pompas do teatro. Cada "entrada" do rei, cada festa, do coroamento ao enterro, é uma representaçăo solene. A corte é um balé ao redor do rei, e os movimentos desse balé são regulados pelas leis da etiqueta espanhola, rigorosas como as leis da composição musical. Esta etiqueta é a muralha impermeável, pela qual o rei está separado de todos os outros homens, como o "espaço separativo" da cena barroca está isolado da sala dos espectadores. O rei barrocó está colocado numa cena que é o "theatrum mundi", o Gran Teatro del Mundo: o mundo gira em torno dele.

Esta representação teatral, que faz do rei um deus terrestre, leva a compreender mal o espírito do Estado barroco. Sim, é uma representação, mas é só uima representação. Representação de realidades mais altas, realidades divinas. $O$ rei barroco está situado táo alto porque é o ápice de um Estado que tem, de alto a baixo e inteiramente, uma significaçăo religiosa: ele' é a imagem de um outro mundo: O pensamento e a realidade política do Barroco estáó imbuídos dé uma "mística do Estado" (33), que se exprime na criaçáo de santuários políticos e religiosos ao imesmo tempo (Escorial, Mariazell); sob a proteçáo dos países pela nomeaçăo de "santos nacionais", "patronos"; no culto do patrono especial dos reis, Sáo

(32) Max Weber - Wirsschaft und Gesellschaft, 1922.

(33) E.K.Winter -Staatsmystik (in: Stanatslacikon des Goerres - Gesellsebafț, vol. V) 
José, cuja festa, criada em 1481, só se impóe no tempo barroco. $O$ culto josefino tem uma significaçáo profunda: o rei tem mais necessidade de proteçáo que os outros homens, porque ele está mais exposto às tentaçóes. Como a tentação é assunto predileto do teatro barroco, a tentação é assunto principal da história barroca: a tentação do vício, da heresia, da tirania; a luta dos Jesuítas, confessores dos reis, aí se impóe.

Pois, como o rei representa, "hic et nunc", a glória, sua corte representa, "hic et nunc", o mundo em toda sua corrupçáo mortal, que justifica todo pessimismo. A fuga das cortes corrompidas é, segundo o modelo de Horácio (Epod. II), tema predileto da poesia barroca. As lamentaçóes sobre a maldade $\mathrm{e}$ a iniqüidade das cortes enchem o século. $O$ drama espanhol gosta de opor à corte, a pureza da aldeia (Alcalde de Zalamea, El villano en su rincon, de Lope de Vega). Uma das maiores tragédias barrocas, The Revenger's Tragedy (1607) do inglês Cyril Torneur, passa-se numa corte, cuja corrupşão é inaudita; mais barroco ainda, James Shirley trata em The Traitor a história do príncipe Lorenzino de'Medici que se fazia de alcoviteiro e clown na corte de Florença, para corromper seu primo, o Grăo-Duque tirânico Alexandre, e matar por fim o tirano; um assunto que volta muitas vezes à cena barroca. "A corte é uma caverna de assassinos", diz o dramaturgo alemão Andreas Gryphius, em sua tragédia de terrores Leo Arminius. Até na corte papal de Roma observa-se o jogo das intrigas malignas das eleiçóes papais, que Pastor descreveu minuciosamente (34), e para as quais Joseph Bernhardt encontrou a fórmula feliz "Entre Versailles e o Escorial"; o grande dramaturgo espanhol Tirso de Molina fala disso em La elección por la virtud. Essa tradição de corrupçáo excessiva das cortes sobrevive ao século XVIII e enche, com seus furores pré-revolucionários, as peças do "Sturm und Drang" alemão, como Kabale und Liebe, do jovem Schiller, onde a felicidade de um jovem casal inocente é destruída pela imbecilidade de um marechal da corte, instrumento das patifarias de um secretário da corte.

A corte barroca justifica, pois, uma concep̧áo pessimista do mundo; e essa corte é táo poderosa que o destino dos homens simples depende dela. Os segredos da corte, impenetráveis para os simples mortais, sáo os segredos do destino, as "constelaçóes funestas"; uma única personagem conhece esses segredos: o "secretário", palavra que tem, no século XVII, uma significação inquietante e funesta.

As personagens principais da corte são três: o rei, o intrigante e o tribuno. Todas as outras, os grandes, os cortesáos, os domésticos, náo

(34) Pastor - Geschichte der Päpste, vols. X.XIV. 
passam de coro, e o povo, abaixo deles, são os figurantes, as marionetes mudas da comédia de máquinas barroca.

O Barroco sabe distinguir entre a peruca e o homem. No rei, vê-se, antes de tudo mais, o homem infeliz, carregado de imensa responsabilidade perante Deus, exposto a todas as tentaçóes da corte. A maior dessas tentaçóes é tornar-se tirano. Mas o tirano é, também ele, um infeliz, e o Barroco vê o infeliz, o mártir, onde nossas falsas perspectivas só nos deixam ver o déspota: o rei Felipe II, o monstro preferido dos historiadores protestantes e liberais, náo se chama por acaso "El gran Seneca de España" na peça de Perez de Montalbán. Sêneca é o modelo do estóico, e Felipe II é o modelo do domínio doloroso de si mesmo, para servir o Estado e o povo, até essa atitude inumana que é própria ao estoicismo; o Baeto, na tragédia do holandês Pieter Cornelius Hooft (1607), é um equivalente protestante dele. É esse estoicismo que destrói os poderes infernais da corte, ainda que por meios inumanos, despóticos. O tirano barroco, como Walter Benjamin se exprime, carrega, também ele, os pecados do mundo.

Todo o veatro barroco é o teatro da vontade. A propria morte do herbi é sua vitoria, pois na morte a perturbação do mundo é vencida.

Nisso o tirano assemelha-se ao seu contrário, o intrigante. $O$ intrigante é proteiforme: aparece como ministro, de que o Sejanus de Ben Jonson é um modelo; como "secretário particular", figura que parece involuntariamente criada pelo nobre e infeliz secretário do rei Felipe II, o doutor Antonio Perez, e que a tradição dramática persegue, até o malvado secretário Wurm, em Kabale und Liebe de Schiller; o intrigante aparece como monge misterioso, figura certamente criada pelo Pe. Joseph, "eminência parda", secretário particular de Richelieu, e que a imaginação dos historiadores protestantes acredita reconhecer em cada Jesuíta, confessor de um rei. Mas, como o intrigante do teatro barroco, $o$ intrigante da corte $\epsilon$ também, no fundo, um infeliz, um misantropo por desespero, um mártir negativo que "peccata mundi secum portat" um demônio, enganado no fim.

A civilizaçāo barroca é muito artista; náo recusa certa admiraçăo pelas artes e pelos refinamentos do intrigante. Compara seu jogo a um jogo de xadrez que ela acompanha, tremendo. A política $\epsilon^{\prime} a$ arte do diabo. Até esse dia, o odor de enxofre emana da diplomacia, invençáo do século XVII, e cujo mestre consumado chamar-se-á Talleyrand. A curiosidade trêmula, mas intrépida, dos moralistas quererá desvendar esses segredos diabólicos, e o primeiro desses moralistas, Maquiavel, teve o destino de emprestar seu nome à arte do diabo (35).

Contra o "maquiavelismo" da política barroca, ergue-se, desde o início, uma oposição vigorosa. Já em 1564, as obras do grande

(35) Charles Benoist - Après Machiard, 1936.

Estudos Avançados, 4(10) 
florentino encontram-se no Index. Em 1592, o Pe. Antonio Possevin S.J. escreve, contra o maquiavelismo, seu Iudicium, livro mordaz e decisivo. A Política de Dios (1626) do grande Francisco Gomes de Quevedo, tida por muito tempo como uma utopia cristá, é a defesa vigorosa dos princípios do Estado cristão contra a política maquiavélica. A Idea de un principe politico cristiano (cerca de 1640) de Diego Saavedra Fajardo é antimaquiavélico, com opinióes que resvalam no liberalismo moderno.

São os advogados dos povos contra as artes refinadas do cortesăo diabólico. Poderiam ser chamados os "tribunos". Falam em nome do povo, porque o povo barroco é mudo comó os figurantes do balé barroco. À política do diabo eles opóem uma política cristã, uma "Política de Dios", uma "politica celeste", como diz o Pe. Antonio Vieira S.J..

Os Jesuítas são, com efeito, os protagonistas no tribunato barroco. Entre os autores mais eminentes dessa direção política, encontramos dois confessores dos Imperadores habsburguenses, o Pe. Guilelmus Lamormaini S.J. (Idea principis christiani: 1638) e o Pe. Adam Contzen S.J. (Politicorum $1 \mathrm{X}$, dedicados ao imperador Ferdinando II). Acreditou-se que eram utopias todos esses livros; do mesmo modo como se acreditava que eram declamaçóes retóricas as "orationes pro Bruto" dos colégios jesuítas. Há um pouco mais.

Sem dúvida, a teoria da soberania do povo tem, no Pe. Francisco Suárez S.J., outra significaçáo que em Rousseau; por isso, como para toda soberania, Suárez exige uma base religiosa. Uma base religiosa encontra-se ainda na "democrazia cristiana" de Tommaso Campanella, expressáo pela qual deixo aliás a responsabilidade a De Sanctis (36). Mas Campanella é já utopista, e os Jesuítas sáo realistas. Quando o Pe. Antonio Vieira S.J. reclama, no sermão de Sto. Antonio, de 14 de setembro de 1642 , uma política de impostos igualitária, isto tem um sentido real. Enfim, toda a "política indigenista" dos Jesuítas é um tribunato. Um tribunato inspirado pelos princípios do cristianismo, um tribunato que náo nega o poder real mas o condiciona pela preservação desses princípios cristãos. Os Jesuítas têm aí, nesses tempos, muitos êmulos, e encontram-se, entre eles, os Puritanos da jovem colônia americana de Massachussets (37). Uma das explicaçóes mais claras desses princípios é a "Harmonia política dos documentos divinos com as conveniências do Estado" (1651), de Antonio de Souza de Macedo, em que o direito do povo de se revoltar só é suspenso pela

(36) Francesco de Sanctis - Storia della letteratura italiana (ed. Morano), vol. II, p.225.

(37) Gustav Mueller - Americanische Philosophic, 1936. 
devoção ao príncipe. A encarnação mais pura do "tribunato" barroco é o príncipe Segismundo da Vida es sueño: ele sucumbe, quando toma as atitudes de um tirano, e vence quando se coloca como tribuno do povo; mas a vitória é condicionada pelo domínio estóico de si mesmo perante seu pai, estoicismo que distingue o monarca cristáo. $O$ tribuno, como o rei, não passa de um representante: ambos representam a intervenção divina nos destinos do mundo.

Toda política barroca é de inspiração religiosa. A "vida es un frenesí", um campo de batalha, em que os exércitos de Deus e do Diabo se combatem. A política é a batalha decisiva: aí, é preciso escolher entre a decisáo política e a decisão religiosa. A Cosmarchia do Pe. Jacobus Bidermann S.J. representa essa batalha em cena. Esta cena é o mundo, como o mundo é um teatro. As relaçōes entre eles devem ser encontradas.

\section{A Função Política do Teatro Barroco}

Identifica-se com freqüência o teatro jesuítico e a "comédia escolar". Com efeito, os Padres da Companhia de Jesus punhamm suas artes teatrais a serviço das atividades pedagógicas. As representaçóes do Collège de La Flèche eram especialmente famosas, e as do Collège de Rouen, onde estudava o jovem Corneille, certamente não eram más. Hoje em dia, vêem-se ainda as salas esplendidamente ornadas, dos colégios jesuítas extintos, em algumas pequenas cidades de província, onde não há mais, desde então, nenhuma vida teatral. Sem dúvida, essas representaçōes tinham fins pedagógicos; muitas vezes serviam aos estudos gramaticais e ao professor de retórica.

Mas esses Colégios não eram comumente escolas secundárias. É preciso náo esquecer que toda a elite das juventudes francesa, espanhola, italiana, austríaca foi educada nesses colégios, e que os negócios políticos do futuro dependiam da formação espiritual e intelectual dessa elite. $O$ teatro jesuítico é um instrumento pedagógico de um grande estilo. Algumas dessas pequenas cidades de província mencionadas eram então centros políticos, como Lucerne, capital da Suíça católica, onde se representava diante dos membros do "Grand Conseil". Em Munique e em Viena, os Padres faziam o possível para deslumbrar as cortes real e imperial pela magnificência das representaçóes; e não era uma espécie de publicidade, de propaganda para as escolas. Lá também, fazia-se pedagogia política, mas desta vez para os adultos, para os reis e para os próprios ministros.

Essas representações fazem parte integrante do "tribunato"jesuítico: as peças são escritas, escolhidas, encenadas para representar aos 
poderosos desta terra certos princípios de política cristá, para "hacer más representables los conceptos". O teatro barroco tem uma funçáo de pedagogia política.

O tempo está convencido, em geral, de que a arte preenche aí seu fim específico. No prefácio da primeira comédia barroca, Il Candelaio, Giordano Bruno explica o título de sua peça como "una candela destinata a illuminare le ombre delle idee". As mesmas "sombras das idéias" encarnam-se nas personagens do Télémaque, romance de Estado de Fénelon, e é preciso notar que os "romances de Estado" barrocos distinguem-se dos do século XVI e do século XVIII pela atitude mais pedagógica que crítica. A mesma observaçáo se aplica aos numerosos "espelhos do verdadeiro príncipe", como os de Geronimo Mengozzi (1614) ou de Théodore Jaquemont (1628), dos quais o mais famoso, o Basilikon doron (1607) foi escrito para o próprio rei Jaime I da Inglaterra.

Mas o teatro produz maiores resultados. Gustave Lanson, falando da significaçăo política do teatro de Corneille, diz: "Em Othon, em Pulchérie, em Juréna, é al que se deve ir procurar o romance verdadeiro dos costumes políticos do século XVII" (38). A tragédia barroca é tragédia política: ela representa os reis como são e como deveriam ser. Distingue o verdadeiro rei do falso rei; é por isso que a história do falso tzar Demetrius está em voga. Outro dos assuntos prediletos do teatro barroco, o sonho, tem sua significaçáo pedagógica: na Vida es sueño, a concepçáo do sonho eleva-se à verdadeira consciência e dignidade real. As grandes peças que o Pe. Nicolaus Avancinus S.J. fez representar em Viena (Theodosius Magnus, 1654, para o casamento de Ferdinando IV; Cyrus, 1673, diante do imperador Leopoldo I), essas peças mostram o bom príncipe como servidor do Estado e do direito, e o tirano como servidor de seus desejos demoníacos. Todos os artifícios da encenaçáo servem ao fim de " hacer más representables" essas virtudes celestes e esses vícios infernais. O Belisarius do Pe. Jacobus Bidermann S.J., representado em Munique em 1607 é uma peça diretamente política, quase ameaçadora; as desventuras do general bizantino Belisário provam que a Fortuna, a deusa caprichosa das mudanças políticas, não passa do instrumento vingador da Providência Divina. A peça comove profundamente o príncipe e seus ministros; atinge o fim que Calderón exprimiu na Vida es suefio:

Sirva de ejemplo este raro

Espectáculo, esta extraña

Admiración, este horror.

(38) Lanson, 1.c. 
... o Estado barroco é a apoteose do monarca. Orei representa, "hic et nunc", a glória do outro mundo.
Os Jesuítas conceberam e realizaram o que os clássicos alemães de Weimar chamavam, segundo a fórmula de Schiller, a "Schaubühne als moralische Anstalt", "o teatro como instituição moral".

Esta definição pedagógica do teatro é propriedade coletiva do Barroco. Compreende-se desta maneira toda a arte. "Depois da política", diz Alessandro Tassoni (Pensieri diversi, 1620), "e de tudo que dela depende, vêm as artes muito nobres, a história, a poesia e a retórica, para instruir os príncipes, os povoś e todos os que se ocupam dos - negócios públicos" (39). O teatro está incluído nisso, como a Pratique du théatre (1657) do abade d'Aubignac prova, e a concepção pedagógica do teatro é sobretudo comum aos teóricos jesuítas (40).

Essa teoria pedagógica vem da antigüidade, ela é o malentendido moralizante da "Khatarsis" aristotélica. Mas o próprio Aristóteles não compreendeu a significação religiosa da grande tragédia grega, e o modelo antigo da tragédia barroca não é Sófocles, mas Sêneca, o moralista estóico. $O$ Barroco é um tempo de grandes angústias religiosas, nós o vimos; a concepção moralizante de seu teatro năo se adapta a isso muito bem. Para esclarecer a contradiçáo, ouso aventurar uma analogia, que não é absolutamente uma explicaçáo, sublinho, mas apenas uma analogia para facilitar a compreensáo.

O maior poder espiritual do Barroco é o Concílio de Trento. $O$ Concílio, que devia defender a ortodoxia contra os reformadores, nāo encontrava nada para mudar nas verdades da fé; no máximo, podia-se defini-las mais estritamente. Neste sentido, não há "reforma tridentina" nem "contra-reforma". Mas era possível e mesmo necessário reformar a disciplina moral na Igreja, e o Concílio cumpriu bem sua tarefa. Mas esse processo que se tornava exemplar, se aplicaria mal à teoria do teatro. Os teóricos do teatro náo encontrariam nada para mudar nas "categorias" trágicas da antigüidade; eles se contentavam em transformar as concepçóes religiosas da tragédia antiga em concepçōes da moral cristã. Isso não fazia mal, enquanto a grave preocupaçáo moral do Barroco reinava. Mas quando essa angústia religiosa desapareceu, no século XVIII, a moral teatral perdia seus rigores e se transformava em oca declamação. Os terrores da tragédia barroca perdiam a significação: as peças de Crébillon pai produziam estupefação, sem aterrorizar. A pedagogia moralizante podia sobreviver; mas o grande teatro barroco desapareceu com a preocupação religiosa que fez tremer os próprios príncipes. A tragédia

(39) Citado por Benedito Croce - Estetica come scienza dell 'espressione e linguistica generale ( $3^{\mathrm{a}}$ ed.), p.191.

(40) J.Zeidler - Studien und Beiträge zur Geschichte der Jesuitenkomiodie 1891; os autores, cf. K.Sommervogel - Bibliographic de la Compagnic de Jesus. 
do século XVIII não faz ninguém mais tremer. A angústia religiosa foi substituída pelo sentimento de segurança que as riquezas materiais fornecem, pelo espírito burguês.

Com efeito, a vitória do sentimento de segurança burguês, laico, é o fim do teatro barroco. Para esclarecer esta tese, seja permitida uma digressáo sobre a comédia barroca. A comédia barroca, também, servia a tendência ascética de destruir a fachada pomposa do mundo. Mas, desta vez, a tendência ascética náo se dirige contra os vícios dos reis, mas contra as tentativas do homem do povo, burguês, de arrogar-se. uma situação social que não convém a seu estado. É preciso provar-lhe, também, que "la vida es un frenesí, una ilusión" (41). As etapas teatrais dessa "ilusão cômica" são Jacobus Usurarius do Pe. Jacobus Bidermann S.J., o Fidalgo aprendiz de Francisco Manuel de Mello, o Bourgeois gentilhomme de Molière. O teatro barroco gosta de servir-se, para esse fim cômico, do assunto trágico "da vida que é um sonho"; representa o sonho pedagógico de um camponês bêbado que se crê,, por um só dia, grande senhor: assim, no prólogo de Taming of the Shrew de Sheakespeare, até a última e mais genial comédia barroca, o Teppe pa berget do grande dinamarquês Ludwig Holberg (1725). E que a ascensáo social passa por imoral. Mas o advento da burguesia no século XVIII transforma essa concepçáo moral; o assunto desaparece da cena. Isto não passa de um sintoma. O teatro perdeu a preocupação religiosa e ganhou, em compensaçáo, a segurança burguesa. No teatro dois caminhos possíveis abrem-se: ou renunciar a todas as concepsóes barrocas ou transformá-las.

O primeiro caminho é a ópera. A tragédia barroca, com suas máquinas, seus "soli" e seus coros, seus balés e seus figurantes encerra já toda a ópera em germes. $O$ barroco vế os homens como marionetes do festim; no século XVIII, não é mais permitido formular essa concepção; ela sobrevive apenas na música, a língua que não pode mais ser compreendida intelectualmente, e Beaumarchais dirá com desdém: "Hoje em dia, o que nâo vale a pena ser dito, canta-se". Contra a opiniāo muito generalizada que crê que a ópera é uma arte aristocrática, sou partidário da opiniáo de Paul Bekker (42): a bpera não é um gênero aristocrático, mas burguês. A ópera aristocrática do século XVIII não passa de um frágil eco do teatro barroco, hoje esquecido. Mas a ópera burguesa vive ainda: começa pelas Bodas de Figaro de Mozart e o Barbeiro de Sevilla de Rossini, cujos libretos servem-se das comédias burguesas, revolucionárias de Beaumarchais; as comédias musicais são o reverso cômico da ópera trágica

(41) E.Flemming - Die Barocklomidie, 1932.

(42) Paul Bekker - Wardilungen der Oper, 1933. 
revolucionária, de Cherubini, que não sobreviveu à tranqüilização conservadora burguesa no século XVIII.

O outro caminho: substituir diretamente a preocupaçáo religiosa pelo sentimentalismo burguês. $O$ homem do barroco era estóico pessimista. O homem do século XVIII é otimista e lacrimejante. Isso começa pela transformação de um assunto da tragédia antiga em drama lacrimejante: a Mérope do Marchese Scipione Maffei, em 1713. A comédia lacrimejante domina o século XVIII, de Lillo a Diderot; ela não se passa mais na corte do rei, mas na casa do pai de família. Entre os últimos dramas lacrimejantes há Eugénie de Beaumarchais, do mesmo Beaumarchais cujas comédias inauguram a ópera moderna social, burguesa, do século XIX; Augier, Dumas Filho e Ibsen o seguirão.

No palco, o espírito burguês suplantou o espírito barroco. Se a tese da identidade de estrutura interna do teatro e do Estado barrocos se confirma, é preciso não se contentar com a constatação fácil de que o teatro e o Estado barrocos caíam juntos. É preciso coordenar o caso político do teatro barroco e a tragédia do Estado barroco, para estudar a identidade estrutural desses dois processos históricos.

\section{A Tragédia do Estado Barroco}

Bernhard Groethuysen (43) estudou as origens do espírito burguês na França. Os três (sic) volumes provam inteiramente nossa tese de que o sentimento de segurança burguês segue diretamente a perda da preocupação religiosa do barroco.

Um contemporâneo dessa evolução francesa é o inglês Shaftesbury: ele faz do estóico sombrio do Barroco um estóico sorridente (44); substitui o sentimento trágico da vida pelogood humour. Essa transformaçáo é significativa.

Groethuysen explica-nos como o burguês substitui o pessimismo barroco, hipnotizado pelo pensamento da morte, pela afirmaçáo da vida, sem se preocupar mais com o aniquilamento. $A$ insegurança do destino barroco $e ́$ afastada por fatos irrefutáveis: as leis da física, as cifras do livro de contas. A morte náo é mais um acontecimento metafísico, mas a transição da casa de uma mão para outra. Esta vida presente $\hat{e}$, para o burguês, de uma realidade dura, que o mundo de sonho barroco jamais conheceu. No lugar das esperanças de recompensa no outro mundo, o burguês prefere as felicidades menos

(43) Bernhard Grothuysen - Die Entstelnung der bïrgerlichon Welt: und Lebensanschasunng in Frankreich, 2 vols., 1927-1930; id., Les origines de l'csprit bourgeois en France, 1927.

(44) E. Tiffany - Schaftesboury als a Stoic, 1923. 
esplêndidas, porém mais palpáveis, ospetits bonheurs de Fontenelle. No lugar dos impulsos de expansão mística em direção ao além, o burguês é movido pelos impulsos de expansão social, através das fronteiras da ordem corporativa, que ele gostaria de romper. Ainda ontem o Pe. Bidermann S.J. zombava, no Jakobus Usurarius, do burguês e de seus desejos de ascensão social; então, otribuno que queria lutar generosamente pelo povo, é, ele próprio, um Dom Quixote ridículo e anacrônico, que se bate contra os moinhos de vento de uma ordem social, que o burguês já abalou. Náo é mais a moral da humildade cristã que defende os pobres, é a riqueza bem adquirida que exige seus direitos. Mas o desejo de expansáo social choca-se contra um obstáculo que queria impedi-lo de acumular dinheiro: a proibiçăo canônica dos juros do capital.

Depois do estudo de Augusto M. Knoll (45), não é mais necessário descrever as discussóes intermináveis sobre a interdição canônica dos juros. Há, atrás das lutas em torno de um dogma da economia política, uma verdadeira luta das classes, que se servem das definiçóes da graça como das ideologias. Entre os combatentes dessas batalhas, reencontramos o Pe. Jacobus Gretser S.J. e os Jesuítas da Universidade de Ingolstadt, onde o teatro jesuítico sobe ao auge, e, por outro lado, o Marchese Scipione Maffei (Dell impiego del denaro, 1744), o criador do drama lacrimejante. Há sem dúvida uma ligaçáo secreta entre o teatro e as leis monetárias, ligação que não é mais, para nós, misteriosa. Mas, em vez de encontrarmos todos os enigmas resolvidos, uma surpresa desagradável nos espera.

Deve-se supor que os Jesuítas, os homens do teatro barroco, e Maffei, o homem do teatro novo, digladiam acerca do problema dos juros. Mas, ao contrário, batem-se, uns e outro, por certas facilidades a favor dos capitalistas, ocontractus trinus, otitulus legis civilis. Os Padres e o Marquês sáo aliados involuntários contra o Pe. Daniel Concina O.P., rigorista da defesa dos juros. É surpreendente.

Maffei, que nisso representa a burguesia, no mercado e na cena, é conseqüiente. Assim, há uma contradição interna no sentimento de vida do barroco, contradiçáo paralela entre o destino da tragédia barroca e a moral pedagógica de sua teoria. É preciso desatar dialeticamente essa contradiçáo.

Isso é impossível, enquanto a gente se limita às discussóes sobre os juros do capital. Mas há relaçóes muito amplas. Os juros, frutos proibidos da colaboraçáo entre o capital e o trabalho, são simétricos à soberania absoluta do Estado, a qual é o fruto proibido da colaboração

(45) August M.Knoll - Der Zins in der Scholastik, 1933. 
entre o rei e o povo. Em ambos os casos, tenta-se expulsar da vida social a Igreja e seus preceitos, para abrir lugar ao espírito burguês e ao espírito maquiavélico. Contra a tentativa política, a vanguarda da Igreja, os Padres Jesuítas, erigem-se emtribunos: os protagonistas da luta contra o absolutismo são o santo cardeal Roberto Bellarmin S.J. (46), o Pe. Martinus Becanus S.J. (47), o Pe. Franciscus Suárez S.J. (48). É nesse sentido que é preciso compreender suas teorias sobre a soberania. Seus adversários são os representantes, hoje esquecidos, de uma sociologia patriarcal que olha o rei como encarnaçáo dodireito paternoilimitado, para extrair daí conclusóes a favor do absolutismo real. É muito notável que essasociologia patriarcal floresça sobretudo na Inglaterra do rei Jaime I, e da Igreja do Estado anglicano (49); o representante principal, um pouco mais tarde, é Sir Robert Filmer, o autor do Patriarcha sive de naturali potestate regium (50).

Essas duas teorias, a dos Jesuítas e a dos Anglicanos, têm suas bases na antigüidade: a interpretaçáo platônica e a interpretaçáo aristotélica do mito dos Ciclopes. Os Ciclopes representavam para os eruditos da antigüidade os homens primitivos, e fatigavam-se para explicar pela sua maneira de viver as origens do Estado. Para Platão (Politikos, 259 b), o germe do Estado são as famílias, de que os Ciclopes são os pais; para Aristóteles (Politica 1252 a), o germe do Estado são os Ciclopes como indivíduos, isolados nas florestas e desertos. Segundo a interpretação platônica, o poder real encerra todos os poderes paternos; segundo a interpretação aristotélica, o poder real difere essencialmente do poder paterno e é menor, se bem que em um nível mais elevado.

A escolástica, que substitui os Ciclopes pelo Adão paradisíaco conhece as duas interpretações e inclina-se mais por Aristóteles: de Tomás de Aquino (De regimini principium, I, 1) até Suárez. Toda a teoria moderna do contrato social, segundo a qual os homens viviam primitivamente como indivíduos livres e isolados, para associar-se mais tarde por um contrato, todas essas teorias, de Locke a Rousseau, baseiam-se na mesma interpretaçáo aristotélica do mito dos Ciclopes. Aparentemente, a teoria de um Suárez é idêntica. Mas, na realidade, os

(46) Joseph de la Servière S.J. - La théologie de Bellarmin, 1908.

(47) Martinus Becanus S.J. - De pontifice Verteris Testamenti et de comparatione illius cum rege, 1612.

(48) H.Rommen - Die Staatslehre des Francisco Sudrez, 1926.

(49) George Blackwell, William Barclay, Roger Widrington, todos ligados à corte do rei Jaime I, da Inglaterra; seus escritos são acessiveis apenas na velha coleção Monarchia S. Romani Imperii, 1613, de Melchior Goldast.

(50) Escrito em torno de 1650, publicado em 1683; reimpresso em algumas ediçōes dos escritos políticos (p.ex., ed. H.Wilmanns, 1906) de Locke, que polemizou contra Filmer. 
autores católicos supóem aí uma significação muito diferente: para Locke e Rousseau, que negam o pecado original, o homem está sempre na inocência paradisíaca de Adáo, de que ele goza de todos os direitos; para os autores católicos, a situaçăo cósmica do homem foi radicalmente mudada pela queda de Adão. Por isso, o homem perdeu os direitos ao direito natural primário, com suas liberdades ilimitadas. O homem decaído deve contentar-se com o direito natural secundário, que corresponde ao estado de pecado e que permite os poderes de força do Estado, a escravidão. Esse olhar pessimista sobre a situação do homem admite concessóes à evoluçáo social, na querela dos juros, bem como a outros respeitos. Com efeito, a sociologia católica, consciente das realidades humanas, não se obstina nunca em uma oposiçāo sistemática, e aí reside sua força; mas nesses tempos de uma grande transformaçáo social, ela se via limitada ao papel de um pregador de moral; ninguém queria ouvir os conselhos de um Vieira ou de um Bourdaloue, cuja grande inteligência sociológica é sublinhada por Groethuysen. Os abusos de um feudalismo anacrônico persistiam; e a catástrofe tornava-se enfim inevitável. Adáo foi expulso, mais uma vez, do Paraíso, e os Ciclopes do capitalismo apareciam.

Na sociologia um pouco fantástica do Barroco, as teorias sobre Adão e os Cicplopes multiplicam-se. Basta mencionar as especulaçóes sobre a origem hebraica dos povos mais diferentes, as explicaçóes datábua dos povos(Gen., $\mathrm{X}$ ) e de sua relação com as migraçóes; especulaçăo que se reencontra ainda em Vico, onde os Ciclopes desempenham um papel apreciável. Através da genealogia, essas especulaçóes invadem a mística do Estado: tentava-se fundar os poderes reais sobre a origem adâmica etc. da família real (51). Em Robert Filmer, que intitula Patriarcha seu livro sobre o poder real, Adăo é o modelo da realeza patriarcal e, por isso, absoluta.

É esse absolutismo que os Jesuítas combatiam, porque a consequiência dele era o poder do rei sobre a Igreja, o Anglicanismo, o Galicanismo, toda espécie de Igreja Nacional, em mãos do Estado. Mas a luta contra esse erro era difícil. No fundo das duas interpretaçóes, platônica e aristotélica, do estado primitivo, adâmico ou cilópico, da humanidade, há duas teorias opostas da filosofia da história: uma otimista, outra pessimista. A teoria otimista levava à teoria da soberania de Suárez, e degenerava, mais tarde, desembaraçada dos freios do dogma do pecado original, ao otimismo rousseauniano e revolucionário; a teoria pessimista passa por Filmer a todos os teóricos do absolutismo, a De Maistre e a Haller. O Barroco é a encruzilhada dessas teorias: na

(51) Franz Kampers - Die Wendegang der abendlïndischen Kaisermystik, 1924. 
Toda politica barroca é de inspiraçio stigiosa $A$ " vida ss un frenest", um ampo de batalha, em que os rércitos de Deus e do Diabo se combatem.

sociologia católica, o otimismo suareziano e o pessimismo teológico : convivem ainda pacificamente. É o momento em que a pretensão do Estado ao absolutismo e a pretensão da nova burguesia à liberdade econômica se dirigem, ambas, contra as doutrinas da Igreja. Aos olhos dos homens da Igreja, ambos estavam certos e errados, ao mesmo tempo. Era preciso combater e conciliar ao mesmo tempo. Mas, por isso, a contradiçáo interna entre o otimismo sociológico e o pessimismo teológico se revelava. Em virtude do pessimismo teológico, os Jesuítas são os protagonistas espirituais do Barroco; em virtude do otimismo sociológico, eles são ostribunos, a oposiçăo muito leal de Sua Majestade. O conflito entre a afirmaçáo e a negaçăo do. mundo, o conflito principal do teatro barroco, tornava-se conflito interno do Estado barroco; ele os destruiu, um e outro. Os Jesuítas se viam limitados a pregadores, que apresentavam ao Estado e à burguesia o espelho de seu teatro e de seus sermóes, o espelho moralista. Nessa luta, os Jesuítas esgotam-se; enfim; tornam-se as vítimas das cortes corrompidas e furiosas: Mas a dissoluçăo da ... Companhia de Jesus precede imediatamente a queda dessas cortes pela revoluçăo.

Essa tragédia do Estado barroco é muito pouco conhecida; gostaria de hacer más representable el conceptơ por um caso concreto e escolho o caso menos conhecido: a decadéncia do.Estado barroco dos

Habsburgos:. ..

Os livros de história sobre o Império, de 1600 a 1780 mais ou menos, são absolutamente insignificantes; contentam-se com a superfície .. . política, e é preciso procurar os fundos, a evoluçäo religiosa e social, .. nas publicaçóes esparsas. Sobretudo, negligenciou-se inteiramente a .. riquíssima mística de Estado austríaca, interpenetraçáo íntima de . soberania e de religiosidade. Na maioria das vezes, devemos os quadros históricos dessa época a historiadores protestantes que não entendiam nada disso. Só sabiam explicar a política do Imperador Ferdinando II pelo clichê obsoleto aluno dos Jesuítas e reduziam as decisóes do imperador da Contra-Reforma e da Guerra dos Trinta Anos à influência excessiva de seus confessores jesuítas. Na verdade; Ferdinando II era déspota por conta própria, se bem que sempre.... atormentado pelos graves escrúpulos, próprios aos rẹis do Estado e do teatro barrocos; os famosos confessores jesuítas, os Pe. Lamormaini e Becanus S.J., que encontramos entre os tribunos, foram: . ., , , ., ; ; atenciosamente ouvidos e pouco obedecidos (52). Mais influentes que esses confessores eram os monges místicos, de que a corte está cheia.

(52) Cf. b livro muito importante e pouco conheciado do historiador católico Anton Gindely - Geselvidise der Gegenreformution in Bobmen, 1894. 
O mais famoso desses monges era o carmelita Pe. Domenicus a Jesus Maria: por sua intervençáo pessoal, a imagem miraculosa de Sta. Maria de la Vittoria nas mãos, ele tinha decidido a vitória definitiva sobre os protestantes boêmios na batalha da Montanha Branca, em 1620. Mas esses monges místicos não são tribunos; ao contrário, têm alguma coisa dós intrigantes demoníacos da tragédia barroca. Os historiadores protestantes declaravam sempre o confessor imperial Pe. Lamormaini S.J. responsável pela execução em massa dos aristocratas protestantes em Praga, em 1621; mas; desde Gindely (53), sabemos que os Jesuítas Lamormaini e Becanus desaconselhavam ardentemente a decisão funesta, que atraía ao Império Habsburguense a oposição secular e irreconciliável da nação tcheca; o Pe. Dominicus a Jesus Maria, inspirado por uma de suas visóes que a Igreja jamais reconheceu, tinha persuadido o Imperador. Em Roma, desconfiava-se sempre de seus conselheiros irresponsáveis: em 1664, o Núncio apostólico em Viena, Carlo Garaffa, escreve numa relaçáo ao Papa, a respeito de tal monge: Náo é impossível que a Providência se sirva de tais instrumentos; mas temo que suas visóes derivem antes de uma confusão melancólica de sua alma do que de uma inspiraçăo divina (54). O monge, de que fala aqui o Núncio, influenciou profundamente o imperadór Leopoldo I, que representa o auge da religiosidade barroca e da mística de Estado na Austria; o país deve-lhe algumas de suas igrejas e de seus grandes conventos mais significativos, o Pe. Avancinus S.J. apresentou-lhe o espelho de príncipe de suas mais pomposas peças. Mas Leopoldo I é também o tipo do monarca barroco, como o teatro espanhol o conhece: era excessivamente devoto (um pouco mais de trato mundano seria melhor, diz o Núncio), era profundamente melancólico, e de uma incapacidade patológica de se decidir (55). Sua irresolução escrupulosa só podia ser vencida pela intervençáo de outro monge místico, que o dirigia, mesmo contra os ministros e os confessores, o Pe. Marco d'Aviano O. Cap. Deve-se reconhecer que a melancolia do imperador era aprofundada pela alta traiçăo de seus dois ministros, príncipe Johann Averberg e príncipe Wensel Lobkowitz, verdadeiros módelos de intrigantes da corte barrocos. Depois, o imperador desconfiava dos grandes aristocratas, sem poder modificar a organizaçăo feudal de seu Império. Confiava-se inteiramente ao monge, a esse Pe. Marco d'Aviano, cuja intervençăo pessoal decidia, em 1681, a vitória sobre os turcos e a salvaçăo de Viena; verdadeiro sucessor do carmelita Pe. Dominicus, Pe. Marco aconselhou, depois, a conquista de outro reino, então herético: a Hungria.

(53) Gindely, 1.c., p.202.

(54) Archio für österreichische Geschichnforschung, vol. CIII, 1913.

(55) Cf. as cartas do imperador ao Pe. Marco d'Aviano, in: M.Hogret - P. Marco d'Apiano, 1931. 


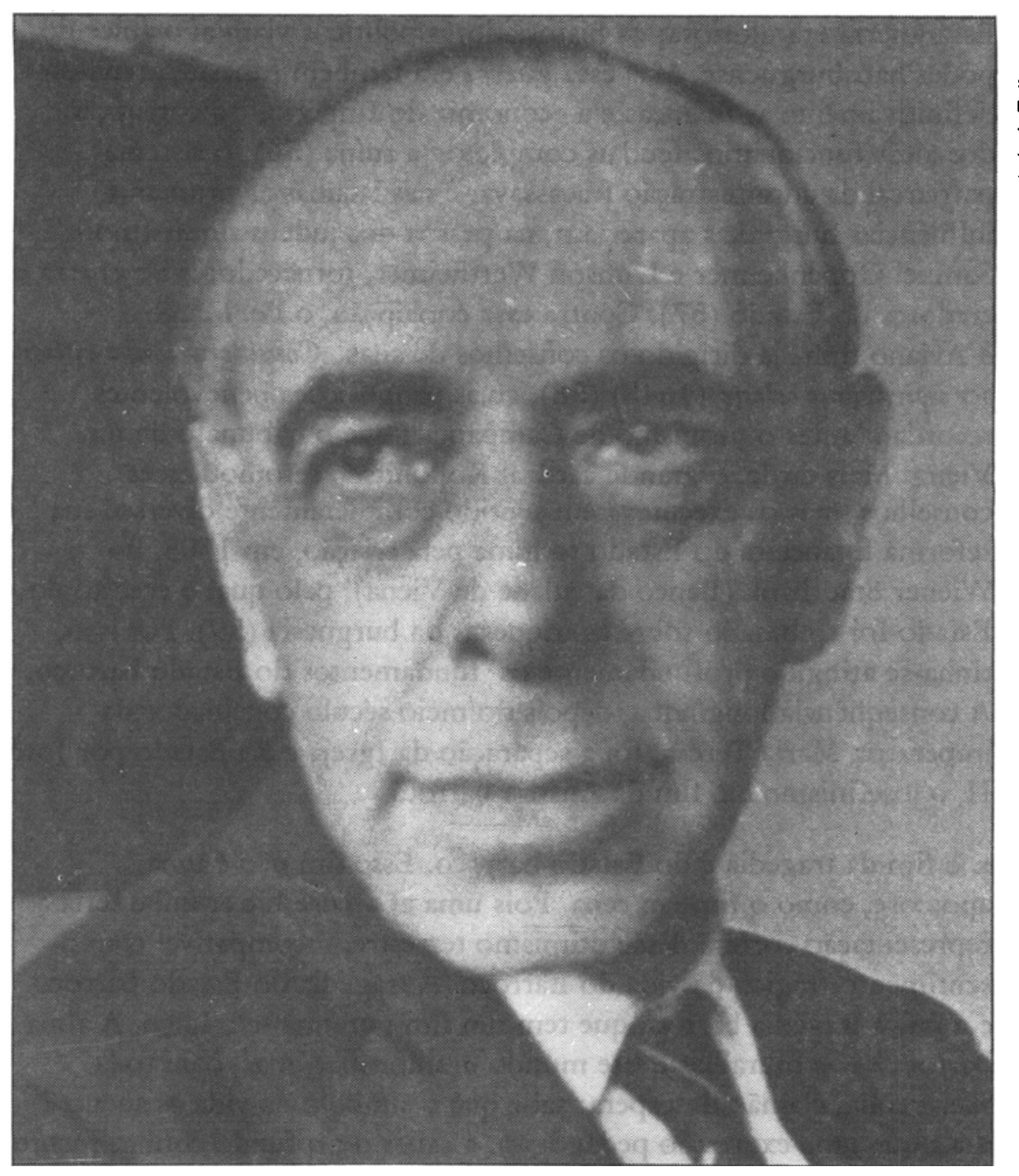

Otto Maria Carpeaux (1900-1978)

Cidadão austríaco e brasileiro, estudou matemática, física e química na Universidade de Viena, onde se doutorou em letras e filosofia. Paralelamente, dedicava-se à música $e$ às ciếncias humanas, orientando-se na linha de pensamento que vai do historicismo alemáo à dialética da História. Patriota, combateu o nazismo e a anexaçáo da Áustria pela Alemanha, tendo sido obrigado (1938) a refugiar-se na Bélgica. Em 1939 emigrou para o Brasil, onde escreveu a maior parte de sua obra (já publicara cinco livros na Europa): $A$ Cinza do Purgatório, ensaios (1942), Origens e Fins, id. (1943), Pequena Bibliografia Critica da Literatura Brasileira (1949-63), Respostas e Perguntas, ensaios (1953), Retratos e Leituras id. (1953), Presenfas, id. (1958), História da Literatura Ocidental, 8 vols. (1958-66), Uma Nova História da Música (1958), Livros na Mesa, ensaios (1960), A Literatura Alemã (1964), O Brasil no Espelho do Mundo, artigos políticos '(1965), $A$ Batalha da América Latina, id. (1966), 25 Anos da Literatura (1968), além de outros livros e numerosos prefácios, introduçóes, verbetes de enciclopédia. 
Essa guerra era gloriosa; os historiadores políticos viam aí o ápice do poder habsburguense. Mas essa guerra era também funesta; arruinou definitivamente as finanças e a economia do Império, e a corrupçáo dos altos funcionários feudais completou a ruína (56); o sistema patriarcal da administraçáo fracassava, e nas lacunas as primeiras influências burguesas apareciam, na pessoa dos judeus riquíssimos Samuel Oppenheimer e Lamson Wertheimer, fornecedores de guerra e credores do Estado (57). Contra essa corrupşão, o Pe. Marco d'Aviano tinha já dirigido os conselhos de suas Considerazioni e riflessi per ispirazione celeste (1648) (58), cujas proposiçōes benevolentes recordam antes o utopismo de Campanella que o tribunato de um Vieira. Mais tarde, o grande cardeal Kollonitsch retomou esses conselhos, mas os executava em sentido completamente diverso; sua reforma financeira do Estado termina pela criação, em 1705, do Wiener Stadtbank (Banco da cidade de Viena), pelo qual o crédito do Estado foi embasado sobre as riquezas da burguesia (59). Por isso, tinha-se atingido profundamente os fundamentos do Estado barroco. A conseqüência longínqua, depois do meio século conciliador da imperatriz Maria Teresa, foi a separação da Igreja e do Estado por José II, o josefinismo e o fim da Áustria barroca.

É o fím da tragédia e do Estado barroco. Esse fim não é uma apoteose, como o fim em cena. Pois uma apoteose hic et nunc seria a representaçáo cortesã desse otimismo terrestre, incompatível com o sentimento trágico da vida do Barroco. A tragédia do Estado barroco é a única tragédia barroca que tem um fim puramente trágico. A alma barroca vê as muralhas deste mundo desmoronar, mas, com toda melancolia, ela não desespera: sabe que o símbolo da vida es sueño é mais que uma exortaçáo pedagógica, a saber o profundo conhecimento metafísico que foi o fundamento do teatro e do Estado barrocos, e que lhes sobreviveu.

Qué es la vida? Un frenesí. Qué es la vida? Una ilusión. Una sombra, una ficción,
Y el mayor bien es pequeño;

Que toda la vida es sueño,

Y los sueños, sueños son.

Agradecimentos:

Ao professor Ruy Gama, pelos termos de arquitetura que mè ajudou a transpor; à professora Ilma Esperança de Assis Santana Curti, que transliterou comigo nomes e textos alemães; e à Jacqueline Mattalia, que teve a paciência de rever e de datilografar essa traduçáo.

(56) Josef Maurer - Kardinal Leopold Graf Kollonitseh, Primas pon Ungarm, 1887.

(57) Franz von Mensi - Die Finarzzen Öterreichs pon 1701 bis 1740, 1890.

(58) Heyret, 1.c.

(59) Maurer, 1.c. 